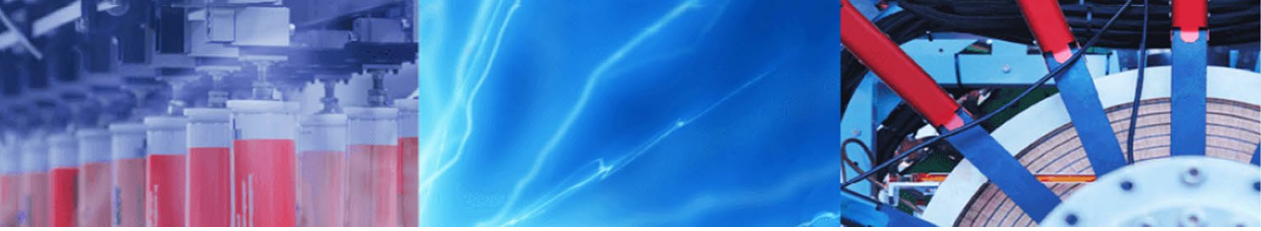

Research Article

\title{
A simple mixing method for polyamide 12/attapulgite nanocomposites: structural and mechanical characterization
}

\author{
Thaís Ferreira da Silva ${ }^{1}$. Guilherme Ferreira de Melo Morgado ${ }^{1}$. Thaís Larissa do Amaral Montanheiro ${ }^{2}$. \\ Larissa Stieven Montagna ${ }^{1}$. Ana Paula Fonseca Albers ${ }^{3}$. Fabio Roberto Passador ${ }^{1}$
}

Received: 22 October 2019 / Accepted: 1 February 2020 / Published online: 10 February 2020

(c) Springer Nature Switzerland AG 2020

\begin{abstract}
In this work, the attapulgite (ATP) was used as a promising mineral clay to prepare polyamide 12 (PA12) matrix polymer nanocomposites. ATP has a relatively low cost compared to other nanoclays and is a very abundant raw material in the northeast region of Brazil. The ATP was characterized by X-ray diffraction (XRD), Fourier-transform infrared spectroscopy and field emission gun scanning electron microscopy (FEG-SEM). The PA12/ATP nanocomposites with 0, 1, 2.5, 5, 7.5 and $10 \mathrm{wt} \%$ of ATP were prepared using a simple blending method in a high-speed thermokinetic homogenizer (3000 rpm) in which the melting of the PA12 and the mixture with ATP occurred by friction, followed by hot pressing and stamping of the specimens. The nanocomposites were characterized by mechanical properties, the degree of crystallinity and crystallite size were calculated by XRD, and the morphological characteristics were observed by SEM. The addition of ATP in the PA12 matrix increased the modulus of elasticity, hardness, degree of crystallinity and the apparent crystallite size of the nanocomposites. The addition of up to $5 \mathrm{wt} \%$ of ATP increased tensile strength and deformation at break; for higher concentrations, the dispersion was not efficient. A major advantage of using ATP as a reinforcement agent for PA12 is the low cost of this material plus the great interaction with PA12 which can dispense the use of compatibilizer agents and/or surface modification in the ATP, making it a potential material to extend PA12's range of applications.
\end{abstract}

Keywords Polyamide $12 \cdot$ Attapulgite $\cdot$ Nanocomposites $\cdot$ Mineral clay

\section{Introduction}

The development of polymer matrix nanocomposites with the addition of mineral fillers is of great interest to the polymer industry. The mineral fillers are added to polymer matrix in order to improve the thermal, mechanical and thermomechanical properties, modifying the surface appearance and the processing characteristics and mainly reducing the costs of the polymer composition [1-4].

In recent years, several nanoclays have been widely studied to improve the mechanical properties of polymeric matrices, especially montmorillonite [5-7], halloysite [8-10] and sepiolite [11-13].

The ATP, also known as palygorskite, is a low-cost, underexplored hydrated magnesium and aluminum clay mineral found in abundance in the northeast region of Brazil, more specifically in Guadalupe (State of Piauí) [14]. The structural formula of ATP is $\mathrm{R}_{5} \mathrm{Si}_{8} \mathrm{O}_{20}(\mathrm{OH})_{2}\left(\mathrm{OH}_{2}\right)_{4} \cdot 4 \mathrm{H}_{2} \mathrm{O}$, where $\mathrm{R}$ is $\mathrm{Mg}^{2+}$ cation, which can be replaced by $\mathrm{Al}^{3+}, \mathrm{Fe}^{3}$ ${ }^{+}, \mathrm{Fe}^{2+}$, in the 2:1 layer octahedral sheet [15].

The morphology of ATP is fibrous with discontinuous octahedral layers toward the fiber and has a large concentration of hydroxyl groups arranged along the octahedron

Fabio Roberto Passador, fabio.passador@unifesp.br| ${ }^{1}$ Polymer and Biopolymer Technology Laboratory (TecPBio), Universidade Federal de São Paulo (UNIFESP), Talim, 330, São José dos Campos, SP 12231-280, Brazil. ${ }^{2}$ Plasmas and Processes Laboratory - LPP, Technological Institute of Aeronautics - ITA, Praça Marechal Eduardo Gomes, 50, São José dos Campos, SP 12228-900, Brazil. ${ }^{3}$ Ceramic Technology Laboratory, Federal University of São Paulo (UNIFESP), São José dos Campos, SP 12231-280, Brazil. 
ends. These groups provide the necessary sites for surface structure modification through various organic reactions, allowing the formation of active surfaces suitable for various applications [16]. Figure 1 shows the modified scheme of the chemical structure of ATP proposed by Bradly in 1940 [17].

ATP has several industrial applications highlighting oil bleaching; refining and chemical processing of petroleum derivatives; filler for various industrial products (paint, pharmaceuticals, pesticides, floor cleaning pads, adhesives and glues); thixotropic stabilizing agent for plastic filler; pet litter (absorbent from physiological dumping of domestic animals); domestic water purification; catalytic support, in oil well drilling fluids, contaminate removal, among others [14, 18-23].

The choice of the polymeric matrix is an important step for the production of nanocomposites. Polyamides are thermoplastic polymers widely used in many engineering areas and stand out as polymeric matrices for nanocomposites. There are many types of polyamides, and their properties vary according to the number of carbons present in their structure and consequently with the number of amide groups present in a given volume of material [24]. Polyamide 12 (PA12) is a polymer obtained from hydrocarbons, petroleum and natural gas. PA12 is produced by polymerizing of laurolactam $\left[\mathrm{CH}_{2}\left(\mathrm{CH}_{2}\right)\right.$ ${ }_{10} \mathrm{CO}$ ] or cyclododecalactam, with 11 methylene units between the -NH-co-polymer chain $[25,26]$. It is attracted due to good processability, low moisture absorption, good resistance to flammability, high mechanical strength, good hardness, fatigue resistance and good abrasion resistance when compared to other polyamides [27].

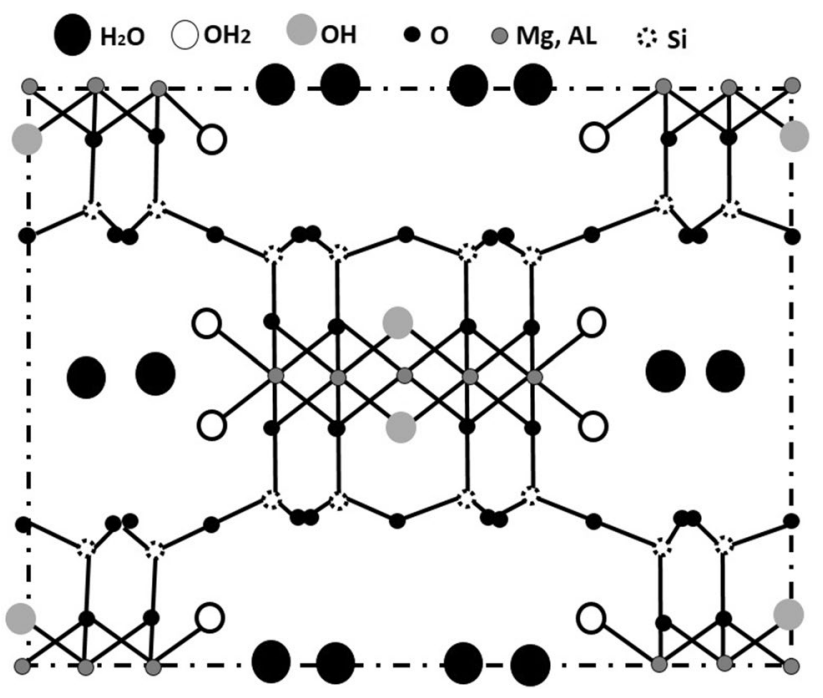

Fig. 1 The chemical structure of ATP
Only a few researchers have studied the effect of ATP on the structure and mechanical properties of polyamides. The vast majority of works involve polyamide 6 (PA6). In general, polyamide/ATP composites are prepared either by in situ polymerization or by extrusion process. Shen et al. [28] prepared PA6/ ATP nanocomposites by in situ polymerization route and showed good dispersion of ATP in the PA6 matrix.

Liu et al. [29] prepared PA6/macrogol/ATP nanocomposites by two-step-melt polymerization method, in which firstly PA6/ATP oligomer was prepared through in situ polymerization and then the nanocomposite was synthesized by the block copolymerization between PA6/AT hard segment and macrogol (PEG) soft segment. The nanocomposites presented higher elasticity and good dispersion of ATP.

Pan et al. [30, 31] prepared ATP/PA6 nanocomposites with different ATP contents (from 0 to $8 \mathrm{wt} \%$ ) by melt compound (twin-screw extruder) and observed an increase in the mechanical properties with the incorporation of $4 \mathrm{wt} \%$ ATP. Xia et al. [32] investigated the thermal degradation by thermogravimetric analyzer behavior of PA6/ATP nanocomposites prepared by melt compound (twin-screw extruder) and observed that ATP can slow down degradation of PA6.

Benobeidallah et al. [33] prepared polyamide 11 (PA11)/ATP nanocomposites by melt compounding and PA11/ATP functionalized by 3-aminopropyltriethoxysilane. It was observed an increase in the elastic and storage moduli of PA11 for both systems, but the enhancement of the mechanical properties was more evident when natural ATP was used. There are no reports on the preparation and characterization of PA12/ATP nanocomposites.

Thus, in the present work, the preparation, structural and mechanical characterization of PA12/ATP nanocomposites with different contents of ATP were investigated. Another goal was the use of a simple and efficient mixing method using a high-speed thermokinetic homogenizer. This mixing equipment consists of a mixing chamber and a rotor. The rotor speed is $3000 \mathrm{rpm}$, and polymer melt occurs by friction in very fast times (less than $1 \mathrm{~min}$ ). This homogenizer enables excellent mixing of the melt polymer with fillers. Polyethylene [34] and polyester [35] nanocomposites with carbonaceous nanomaterials (carbon nanotubes and carbon black) were successfully obtained, where excellent dispersion of nanomaterials in the polymeric matrices was observed. Thus, the use of this mixing technique aims to improve ATP dispersion in PA12 faster and at a lower cost, seeking improvements in the mechanical properties of PA12.

In this study, we are proposing the use of an abundant clay mineral found in northeast region of Brazil, which is 
the attapulgite (ATP) for the preparation of polyamide 12 (PA12) nanocomposites by a simple mixing route.

\section{Experimental}

\subsection{Materials}

Polyamide 12 (PA12) Grilamid ${ }^{\circledR}$ L25 W 20X was produced by EMS-Grivory (China) with a specific mass of $1.02 \mathrm{~g} /$ $\mathrm{cm}^{3}$. Attapulgite (ATP) with specification BRM F 14-EPA 13.04 was supplied by Brasil Minas (Brazil), with basic composition of hydrated magnesium silicate $\left(\mathrm{SiO}_{2}+\mathrm{MgO}\right)$, specific mass of 2.00 a $2.25 \mathrm{~g} / \mathrm{cm}^{3}$ and pH ( 5 wt \% water solution) 7.0 to 11.0 .

\subsection{Characterization of ATP}

The ATP was characterized by X-ray diffraction, Fouriertransform infrared spectroscopy (FT-IR) and field emission gun scanning electron microscopy (FEG-SEM).

The X-ray diffraction was performed using an Ultima IV-Rigaku diffractor with CuKa radiation $(\lambda=1.54056 \AA)$, operating at $0.2^{\circ} \mathrm{s}^{-1}$ and $2 \theta$ ranging from $5^{\circ}$ to $60^{\circ}$.

FT-IR spectra were recorded on a Frontier spectrometer (PerkinElmer, Waltham, MA, USA), equipped with a universal attenuated total reflection (UATR) accessory. Each spectrum was acquired in transmittance mode by the accumulation of 32 scans with a range of $4000-400 \mathrm{~cm}^{-1}$.

To evaluate the morphology of the ATP, field-scanning electron microscopy (FEG-SEM) was performed using MIRA3 TESCAN equipment, with a voltage of $10 \mathrm{keV}$. The ATP was placed on a carbon tape for analysis.

\subsection{Preparation of nanocomposites}

First, ATP was sieved into a 200 mesh screen. All materials were dried for a minimum of $24 \mathrm{~h}$ in an oven at $80^{\circ} \mathrm{C}$ prior to processing. PA12/ATP nanocomposites were prepared using a high-speed thermokinetic homogenizer (DRAIS mixer produced by $\mathrm{MH}$ Equipamentos Ltda, model $\mathrm{MH} 50-\mathrm{H}$ ) rotating at $3000 \mathrm{rpm}$ and mixing chamber with a capacity of $70 \mathrm{~g}$ of material. The mixing, melting and homogenization of the nanocomposites occur due to the high friction generated between the rotor and the material. The mixing temperature was monitored using a thermocouple and reached $200{ }^{\circ} \mathrm{C}$ in $40 \mathrm{~s}$ of mixing. Nanocomposites with $0,1,2.5,5,7.5$ and $10 \mathrm{wt} \%$ of ATP were prepared. After $1 \mathrm{~min}$ of mixing, the homogenized nanocomposites were collected and pressed into $3.2 \mathrm{~mm}$ thick plates in a hydropneumatic press (MH Equipamentos Ltda, model PR8HP) at $200{ }^{\circ} \mathrm{C}$ with a pressure of $5 \mathrm{bar}$ for $3 \mathrm{~min}$. Subsequently, standard test specimens were stamped for the mechanical tensile and impact tests using a CEAST/Instron pneumatic stamper.

\subsection{Characterization of nanocomposites}

\subsubsection{Fourier-transform infrared analyses}

FT-IR spectra were recorded on a Frontier spectrometer (PerkinElmer, Waltham, MA, USA), equipped with a universal attenuated total reflection (UATR) accessory. Each spectrum was acquired in transmittance mode by the accumulation of 32 scans with a range of $4000-400 \mathrm{~cm}^{-1}$.

\subsubsection{X-ray diffraction}

The X-ray diffraction (XRD) was performed using an Ultima IV-Rigaku diffractor with CuKa radiation $(\lambda=1.54056 \AA)$, operating at $0.2^{\circ} \mathrm{s}^{-1}$ step and $2 \theta$ ranging from $5^{\circ}$ to $60^{\circ}$. The XRD was used to determine the degree of crystallinity $(X c)$ and the apparent crystallite size of the samples studied. The degree of crystallinity was obtained through the mathematical deconvolution of the diffractogram in the $2 \theta$ region varying between $15^{\circ}$ and $30^{\circ}$ and calculated through Eq. 1:

$X_{C}=\frac{\sum \text { Acrist }}{\sum \text { Acrist }+\sum \text { Aamor }}$

where Acrist and Aamor are the areas of the crystalline peak and the amorphous band, respectively. The apparent crystallite size was determined by the Scherrer equation (Eq. 2):

$D(h k l)=\frac{K \lambda}{\beta \cos \theta}$

where $k=0.9, \theta$ is the Bragg angle, and $\lambda$ is the wavelength of the $X$-rays and using the values of $\beta$ obtained from the equation $\beta^{2}=\beta_{\text {obs }}{ }^{2}-\beta_{p}{ }^{2}$. The $\beta_{\text {obs }}$ and $\beta_{p}$ are the full width at half maximum of the main peak of diffraction of the sample and of a standard (usually mica), both obtained in the same operating conditions of the equipment.

\subsubsection{Mechanical characterization}

Impact tests were performed on a CEAST/Instron Izod impact testing machine (model 950). The test method adopted was carried out according to ASTM D256-78 [36]. All the test specimens were notched using a manual notch machine (CEAST/Instron, model 9050). All specimens were notched using a CEAST/Instron manual notcher and performed in a 0.01 inch notch. Impact loading was done 
with a $5.5 \mathrm{~J}$ hammer. Five samples of each composition were tested.

The uniaxial tensile test was performed following the ASTM D638 [37] standard, using a universal MTS test machine, Criterion 45 model, with a $50 \mathrm{kN}$ load cell and a crosshead speed of $50 \mathrm{~mm} / \mathrm{min}$. The specimens used were type 1, and five type 1 specimens of each composition were assayed. The Young's modulus was analyzed using analysis of variance (ANOVA), and Tukey-Kramer test $p<0.05$ was considered significant.

Shore $D$ hardness was evaluated using an Instrutherm Shore D durometer model DP 400; ten measurements were performed on each test specimen.

\subsubsection{Morphological characteristics}

SEM micrographs of neat PA12 and PA12/ATP nanocomposites were detected by a scanning electron microscope FEI Inspect S50, operating at $15 \mathrm{keV}$; the samples were cryogenically fractured and coated with a thin layer of gold.

\section{Results and discussion}

\subsection{Characterization of ATP}

Figure 2a shows the X-ray diffractogram of ATP, where the main diffraction peak related to attapulgite, quartz and dolomite was identified with the aid of JCPDF $\mathrm{n}^{\circ}$. $31-0783,1-0,850,794$, and $89-5862$, respectively. The region with the highest ATP diffraction peak intensity is located at approximately $20.8^{\circ}$. Other typical diffraction peaks of this mineral clay were found in the diffraction pattern with lower intensity and were identified at $8.6^{\circ}$ and $19.9^{\circ}$. A region close to $26.7^{\circ}$ is characteristic of the presence of quartz. A region close to $29.3^{\circ}$ is characteristic of the presence of dolomite. All the diffraction is well documented in the studies $[14,38-40]$.
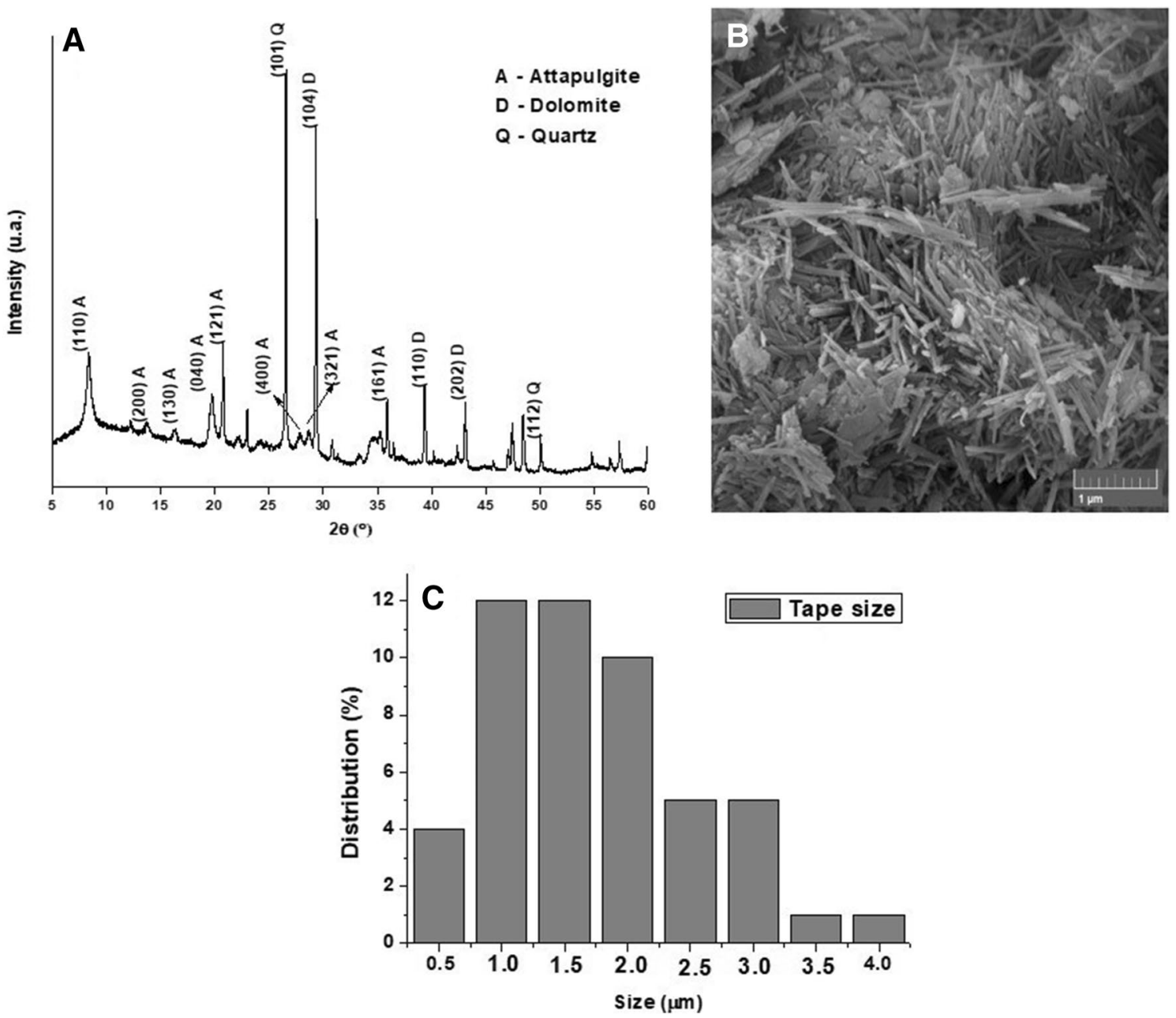

Fig. 2 a X-ray diffractogram and b FEG-SEM micrographs of attapulgite with magnifications of $5000 \times \mathbf{c}$ average length of fiber length 


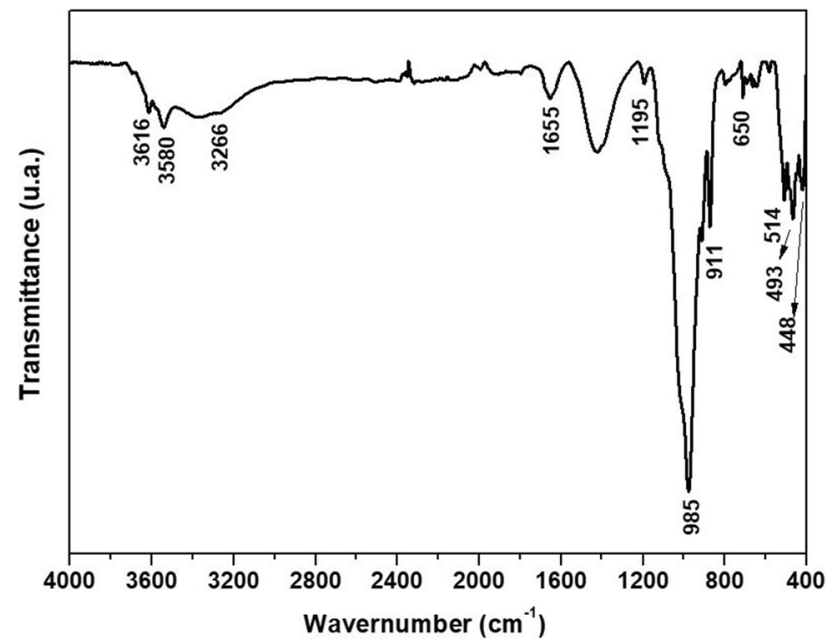

Fig. 3 FT-IR spectra of natural attapulgite

Table 1 Characteristic bands of attapulgite infrared vibration

\begin{tabular}{ll}
\hline Wave number $\left(\mathrm{cm}^{-1}\right)$ & Assignment bands \\
\hline 3616 & $2 \mathrm{M}_{2}-\mathrm{OH}$ stretch where $\mathrm{M}=\mathrm{Al}[41,42]$ \\
3580 & $\mathrm{Al}-\mathrm{Fe}^{3+}-\mathrm{OH}$ stretch or $\mathrm{Al}-\mathrm{Mg}-\mathrm{OH}[41]$ \\
3266 & Zeolite water stretch (Fe-Mg-OH) or \\
& (Al-Mg-OH) [43] \\
1655 & Zeolite water deformation [41] \\
1195 & Si-O-Si stretch [43] \\
985 & Si-OH stretch [44] \\
650 & $\mathrm{M}-\mathrm{OH}$ deformation [44] \\
\hline
\end{tabular}

Figure $2 b$ shows the FEG-SEM micrographs of ATP; it is possible to observe ATP in fibrous forms, forming clusters of tapes and needles of varying lengths [14,23].

Figure $2 \mathrm{c}$ shows the histogram for the more detailed study of the average length of the ATP fibers measured from the FEG-SEM images, in which 50 mineral clay particles were analyzed and counted. According to the measurements, the average fiber length varies from 0.5 to $4 \mu \mathrm{m}$, but with a predominance of $1 \mu \mathrm{m}$ length.

Figure 3 shows the Fourier-transform infrared analyses of the ATP. It is possible to observe the main characteristic bands of metal-bound hydroxyl vibrations present in the regions between 3616 and $3266 \mathrm{~cm}^{-1}$. These bands refer to the $2 \mathrm{Al}_{2}-\mathrm{OH}$ vibrational mode in the octahedron [14, 41]. Absorption bands in a region of lower wavelengths present in the spectrum were identified and are shown in Table 1.

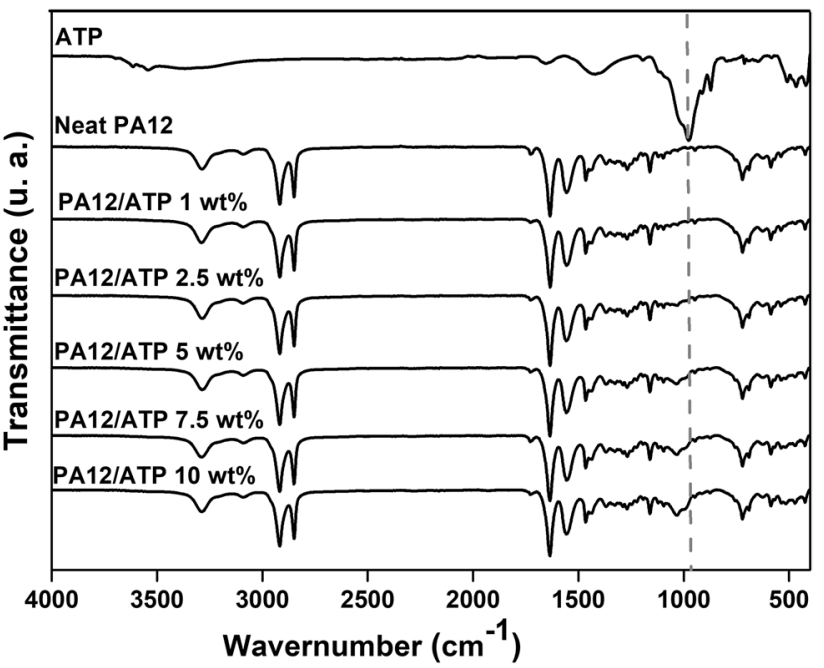

Fig. 4 FT-IR spectra of neat PA12 and composites with 1, 2.5, 5, 7.5 ad 10 wt $\%$ of ATP

Table 2 Characteristic bands of neat PA12 and PA12/ATP nanocomposites with different ATP contents infrared vibration

\begin{tabular}{ll}
\hline Wave number $\left(\mathrm{cm}^{-1}\right)$ & Assignment bands \\
\hline 3289 & $-\mathrm{NH}$ stretching $[45,46]$ \\
2920 & $\mathrm{CH}$ - stretching $[46]$ \\
2843 & $\mathrm{CH}-$ stretching $[46]$ \\
1633 & $\mathrm{~N}-\mathrm{C}=\mathrm{O}$ vibration $[45,46]$ \\
1550 & $\mathrm{C}-\mathrm{N}-\mathrm{H}$ vibrations $[45,46]$ \\
\hline
\end{tabular}

\subsection{Structural and mechanical characterization of PA12/ATP nanocomposites}

Figure 4 shows the Fourier-transform infrared analyses of the ATP, neat PA12 and PA12/ATP composites with 1, $2.5,5,7.5$ ad $10 \mathrm{wt} \%$ of ATP. It is possible to observe that the composites have the same characteristic bands as the PA12. Absorption bands in a region of lower wavelengths present in the spectrum were identified and are shown in Table 2.

Bands in a region $985 \mathrm{~cm}^{-1}$, commonly attributed to the group $\mathrm{Si}-\mathrm{OH}$ stretch and characteristic of ATP, increase in the composites [44]. The addition of large amounts of ATP in the composites increases the peak; however, for this composite the ATP was not well dispersed in the matrix PA12 [47]. It is also possible to observe the displacement of this peak; for the ATP, it is located in $985 \mathrm{~cm}^{-1}$, and for the PA12/ATP $10 \%$ composite, it is located in $1022 \mathrm{~cm}^{-1}$, which is an indication of the interaction of the amide group of PA12 and the hydroxyl of the ATP [48-50]. 


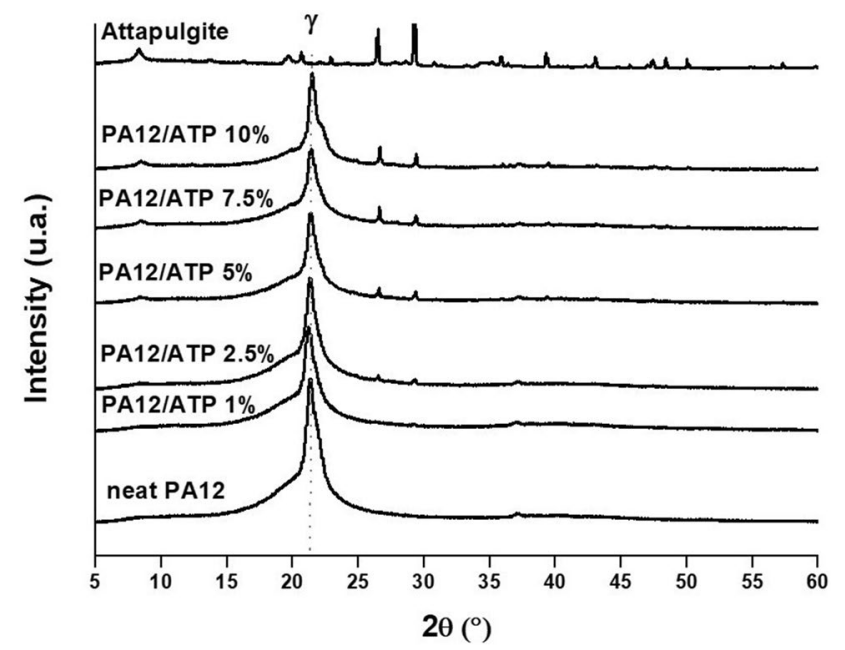

Fig. 5 X-ray diffractogram patterns of neat PA12 and PA12/ATP nanocomposites with different ATP contents

Figure 5 shows the XRD curves for ATP, neat PA 12 and PA12/ATP nanocomposites with different ATP contents 1 , $2.5,5,7.5$ and $10 \mathrm{wt} \%$.

XRD results indicate that neat PA12 has a complex of the two structures with the largest proportion of the form $\gamma$ than the shape of structure $a_{1}$ and $a_{2}$. This may be associated with material processing conditions in the mixing chamber and press molding, followed by the rapid cooling of the mold [51].

In relation to the nanocomposites, the same PA12 behavior can be observed, since the addition of clay in the PA12 matrix contributed to the appearance of the $\gamma$-form of the crystal [52]. Adding great amounts of ATP, the intensity of the $\gamma$-form is increased. This suggests that ATP promotes nucleation and formation of $\gamma$ crystals. Clearly, both ATP addition and cooling rate play important roles in the behavior of PA12 nanocomposites. Yuan et al. [53] studied the crystallization of nanocomposites of polyamide and concluded that with the addition of clay nanoparticles, the growth of the crystalline a-phase disappears and the formation of the $\gamma$-phase of crystals is promoted.
Concerning the nanocomposites, it can be observed that XRD diffraction peaks show gradual loss of the typical ATP peak (in the regions $8.6^{\circ}, 26.7^{\circ}$ and $29.35^{\circ}$ ) with the reduction of the clay content. For the sample with $1 \mathrm{wt} \%$ of ATP, it was no longer possible to observe the typical peak of ATP. This result can be attributed both to the disarticulation of the stacking of the clay layers (possible exfoliation) and to the degree of nanofiller dilution, especially for the $1 \mathrm{wt} \%[54,55]$. Table 3 shows the basal spacing values of PA12/ATP nanocomposites.

By crystallizing in $a$ - and $\gamma$-forms, the crystalline structures of polyamides are widely studied and a pseudohexagonal packing of 21 chains is known as the $\mathrm{y}$-form, whereas a monoclinic or triclinic lattice with chains in fully extended planar zigzag arrangement consists of the a-form [56-58].

Atkins et al. [59] found that the a-form when heated to the melting temperature $\left(T_{\mathrm{m}}\right)$ becomes the $\gamma$-form. Under rapid cooling conditions, this pseudohexagonal phase can be "frozen" [59]. These crystals will revert to the monoclinic phase if heated above the glass transition temperature (Tg); the structure will begin to transform back into the pseudohexagonal phase if the temperature is further increased. The $\gamma$-phase is predominant under rapid cooling conditions and is not thermodynamically stable [60]. Due to the rapid cooling of the process used in this work, the $\gamma$-phase predominates.

The degree of crystallinity and the apparent size of the crystallite are shown in Table 2 . The clay-containing samples had higher crystallites. Increasing crystallites led to an increased crystalline phase; perhaps this behavior may be related to increased surface area of ATP nucleating sites, leading to more efficient nucleation. Similar results were also found in works with PVA/ATP [61] and PHBV/ATP [62], demonstrating that ATP can be used for the production of polyamide matrix nanocomposites without the need for surface modification and/or addition of compatibilizer agents.

In general, the degree of crystallinity, Xc, of nanocomposites increased when compared to polyamide. This can be attributed to the nucleating effect of clay and

Table 3 Values of typical peaks, basal spacing $(d)$, degree of crystallinity $\left(X_{c}\right)$ and apparent crystal size of neat PA12 and PA12/ATP nanocomposites with different ATP contents

\begin{tabular}{lllll}
\hline Samples & $2 \theta$ & $\mathrm{d}(001) \mathrm{nm}$ & $X c(\%)$ & Apparent crystallite size (nm) \\
\hline Neat PA12 & 21.56 & 4.12 & 44.76 & 10.22 \\
PA12/ATP 1 wt\% & 21.25 & 4.22 & 51.44 & 11.75 \\
PA12/ATP 2.5 wt\% & 21.35 & 4.16 & 47.87 & 11.76 \\
PA12/ATP 5 wt\% & 21.35 & 4.14 & 47.05 & 12.17 \\
PA12/ATP 7.5 wt\% & 21.45 & 4.14 & 45.35 & 12.82 \\
PA12/ATP 10 wt\% & 21.46 & 4.12 & 45.78 & 14.11 \\
\hline
\end{tabular}


the formation of the $\gamma$-phase as reported in several studies $[63,64]$; however, as the filler content increases, the degree of crystallinity decreases. At concentrations greater than $1 \mathrm{wt} \%$ ATP, dispersion was not efficient, making the increase in crystallinity smaller. At $1 \mathrm{wt} \%$, it was probably the best dispersion, causing ATP to act as a heterogeneous nucleating agent, creating multiple nucleation points and consequently causing a greater increase in crystallinity. It is also observed that the degree of crystallinity peaks at low filler concentrations ( $2.5 \mathrm{wt} \%)$. These results are in agreement with other research $[65,66]$, which attribute the formation of small and perfect crystals to the flexibility of the chain of polymeric molecules when nucleated by small filler additions, that is, higher filler levels would imply the formation of larger and less perfect crystals, since they would have a smaller number of sites to be nucleated, thus hindering mobility and eventually resulting in a decrease in the degree of crystallinity.

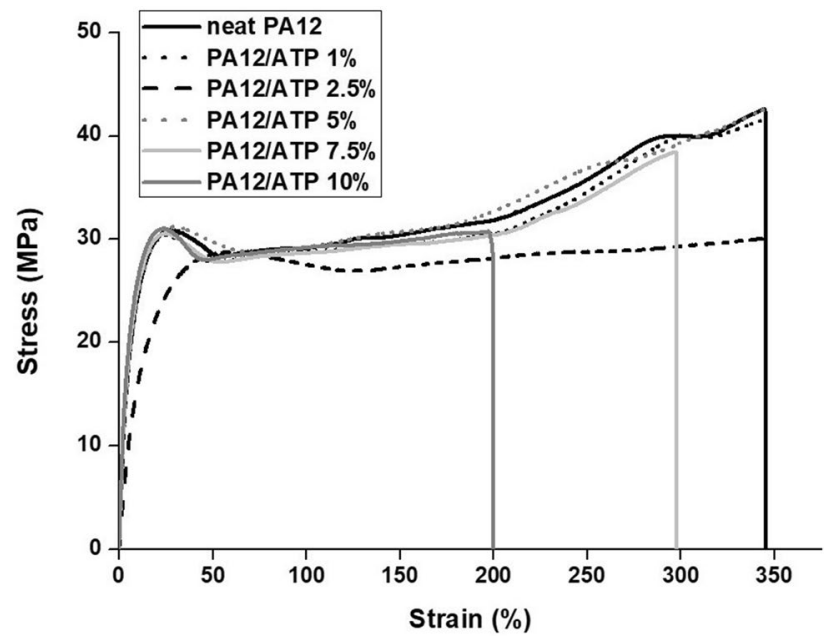

Fig. 6 Stress-strain curves for neat PA12 and composites with 1, $2.5,5,7.5$ ad $10 \mathrm{wt} \%$ of ATP
Figure 6 shows the stress-strain curves, and Table 4 shows the mechanical properties (impact tests, uniaxial tensile test and Shore D hardness).

The addition of amounts greater than $1 \mathrm{wt} \%$ of ATP to PA12 matrix resulted in a reduction in the elongation at break, indicating loss of toughness of the nanocomposites, probably due to the presence of clusters acting as stress concentrators. The reduction in elongation at break is already expected since the load used is ceramic, that is, it is fragile when it is stretched. On the other hand, the increase in ATP contents in the nanocomposites promoted an increase in the stiffness as indicated by the higher elastic modulus and hardness values. The elastic modulus increased by $38 \%$ with the addition of ATP over neat PA12.

Young's modulus was statistically analyzed, and the results were significantly different, $P<0.001$, and the table shows the differences comparing the composites in relation to neat PA12.

The analysis of the results reveals a tendency to increase the hardness of nanocomposites with increasing ATP content, behavior that suggests the reinforcing effect of ATP in nanocomposites.

Regarding the uniaxial tensile, there is an increase in the tensile strength up to $5 \mathrm{wt} \%$ ATP in the nanocomposites. This may indicate an increase in nanocomposite stiffness as a function of lamellar intercalation/exfoliation as indicated by X-ray diffraction analysis. Pan et al. [30] achieved an increase with the addition of $4 \mathrm{wt} \%$ of ATP in PA6 matrix, but with increasing concentration of ATP, a decrease of approximately $15 \%$ in the tensile strength was observed, which is similar to the results reported in this research.

The lower reinforcement efficiency observed for higher clay contents can be attributed to the particle-particle interaction of clay, favoring its re-stacking and crowding rather than dispersion [26]. Besides that, the fibrous nature of ATP can decrease the interaction of ATP and PA12 at a filler level greater than 3 wt\% [67].

Table 4 Mechanical properties of neat PA12 and PA12/ATP nanocomposites with different ATP contents

\begin{tabular}{|c|c|c|c|c|c|}
\hline Samples & $\begin{array}{l}\text { Tensile strength } \\
(\mathrm{MPa})\end{array}$ & $\begin{array}{l}\text { Deformation at } \\
\text { break (\%) }\end{array}$ & Young's modulus (GPa) & Hardness (Shore D) & $\begin{array}{l}\text { Impact } \\
\text { resistance } \\
(\mathrm{J} / \mathrm{m})\end{array}$ \\
\hline Neat PA12 & $43.0 \pm 1.0$ & $421.3 \pm 20.1$ & $0.42 \pm 0.01$ & $64.35 \pm 0.15$ & $\mathrm{~N}^{*}$ \\
\hline PA12/ATP 1 wt $\%$ & $43.6 \pm 0.4$ & $422.6 \pm 12.8$ & $0.46 \pm 0.01^{* * *}$ & $65.60 \pm 1.09$ & $\mathrm{~N}^{*}$ \\
\hline PA12/ATP 2.5 wt $\%$ & $43.9 \pm 0.5$ & $349.6 \pm 7.2$ & $0.51 \pm 0.01^{* * * *}$ & $66.07 \pm 0.55$ & $\mathrm{~N}^{*}$ \\
\hline PA12/ATP 5 wt $\%$ & $44.5 \pm 0.2$ & $348.9 \pm 6.9$ & $0.54 \pm 0.01^{* * * *}$ & $68.00 \pm 0.80$ & $\mathrm{~N}^{*}$ \\
\hline PA12/ATP 7.5 wt $\%$ & $42.2 \pm 0.7$ & $214.6 \pm 6.1$ & $0.55 \pm 0.01^{* * * *}$ & $68.54 \pm 0.17$ & $\mathrm{~N}^{*}$ \\
\hline PA12/ATP 10 wt\% & $41.1 \pm 0.3$ & $218.2 \pm 28.1$ & $0.58 \pm 0.01^{* * * *}$ & $68.87 \pm 0.61$ & $73.6 \pm 3.2$ \\
\hline
\end{tabular}

$N^{*}=$ did not break

One-way ANOVA, significance levels: ${ }^{* * *} p<0.001,{ }^{* * * *} p<0.0001$ (statistical differences compared to neat PA12) 


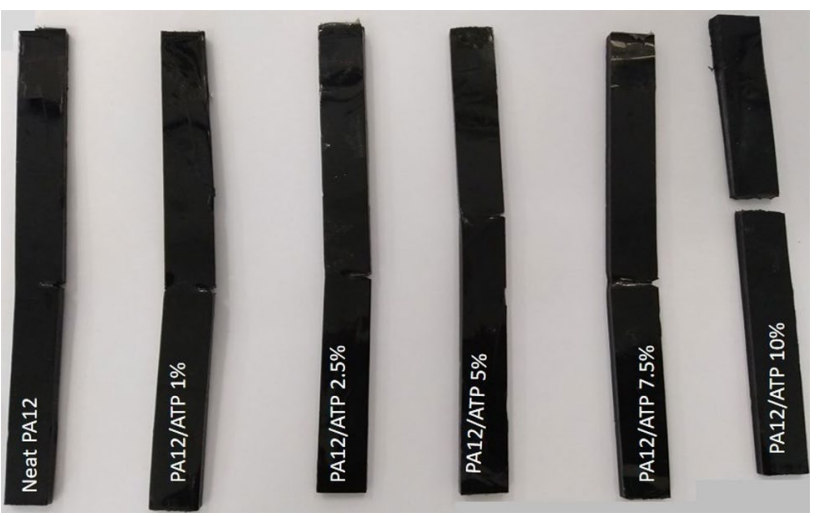

Fig. 7 Neat PA12 and PA12/ATP nanocomposites specimens after Izod impact test

Figure 7 shows the samples after the impact strength test. It is noted that neat PA12 and the PA12/ATP nanocomposites with $2.5,5$ and $7.5 \mathrm{wt} \%$ of ATP do not fracture in the impact test (maximum of $5.5 \mathrm{~J}$ ). These results are in accordance with the polymer datasheet provided by the supplier. However, the only composition that was fractured was PA12/ATP 10\% which presented fracture and impact strength in the order of $71.5 \mathrm{~J} / \mathrm{m}$.

Figure 8 shows the SEM micrographs of the fracture surfaces of neat PA12 and PA12/ATP nanocomposites with 1,5 and $10 \mathrm{wt} \%$ of ATP. These compositions were chosen for the SEM-FEG, because the addition of only $1 \mathrm{wt} \%$ of ATP increased composites crystallinity, $5 \mathrm{wt} \%$ of ATP presented the best mechanical property (higher tensile strength, good Young's modulus, good hardness and did not fracture in the Izod impact test) and composition with $10 \mathrm{wt} \%$ of ATP as it was the maximum added filler. In Fig. $8 \mathrm{a}$ and e, it is possible to observe the fracture surface of neat PA12. Figure $8 \mathrm{~b}$ and $\mathrm{f}$ presents the PA12/ATP nanocomposite with $1 \mathrm{wt} \%$ of ATP, and it is possible to observe well-dispersed bright dots (indicated by arrows) in which the good dispersion of the clay in the matrix is confirmed and the result of the increase in crystallinity for this clay concentration is confirmed.

Figure $8 \mathrm{c}$ and $g$ presents the PA12/ATP nanocomposite with 5 wt $\%$ of ATP, and it is possible to observe the presence of well-dispersed bright dots (indicated by arrows) attributed to the presence of the nanoclay. The SEM images clearly show that a uniform dispersion of ATP throughout the PA12 matrix is achieved and the mixing process contributes to this good dispersion and distribution. Visually, it has no large clusters, but even so, the concentration of $5 \%$ was not efficient in acting as nucleating agent. In Fig. $8 \mathrm{~d}$ and $\mathrm{h}$, it is possible to observe the PA12/ATP nanocomposite with $10 \mathrm{wt} \%$ of ATP where it is observed the presence of ATP agglomerates, indicating that the amount of ATP was large and the dispersion was not effective even using high homogenization process. Similar behavior can be found in the literature $[24,26,32]$. Through close inspection, as shown by arrow in Fig. 8f, some aggregates appear which can cause negative effects on the performance of the nanocomposite and are consistent with the impact strength results of the aforementioned discussion.
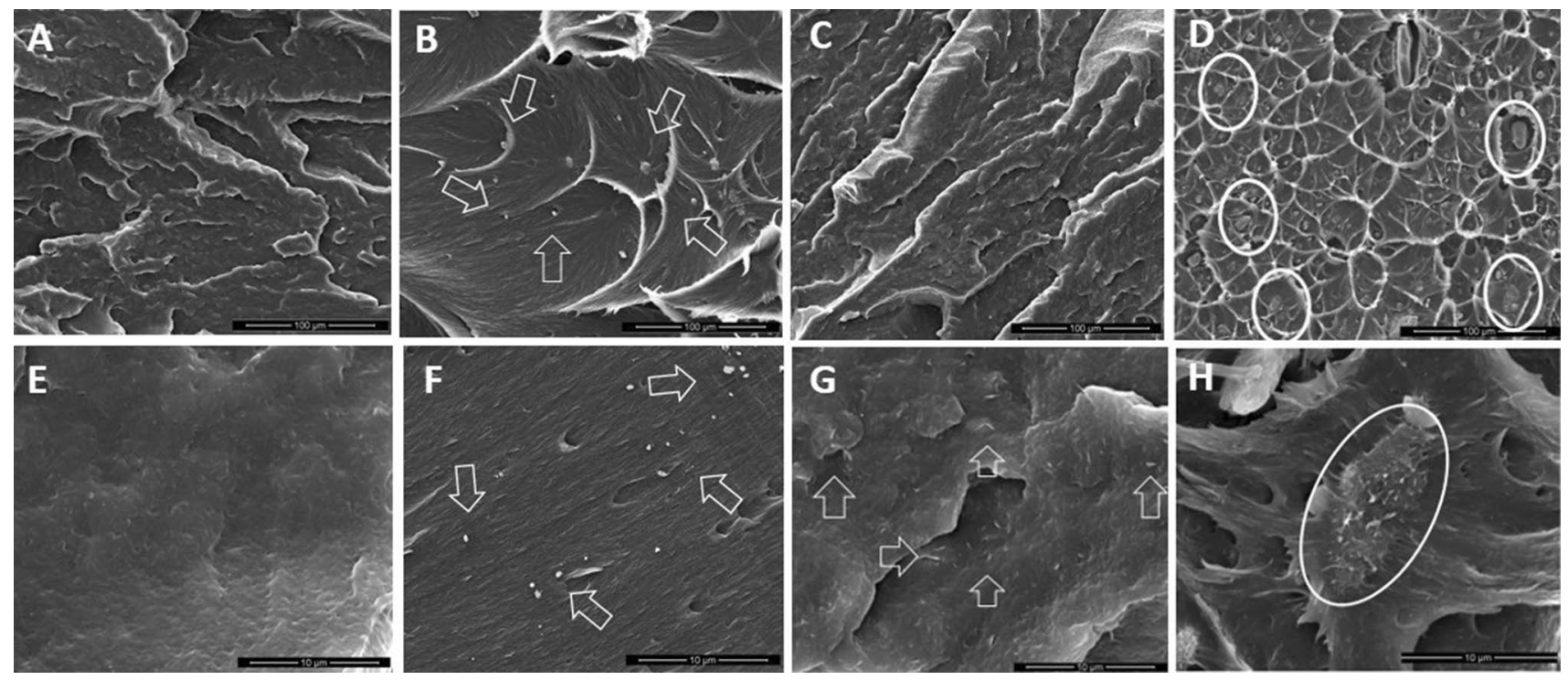

Fig. 8 SEM images of a neat PA12, b PA12/ATP 1 wt $\%$, c PA12/ATP 5 wt $\%$, d PA12/ATP 10 wt $\%$ with magnification of 1000x and e neat PA12, f PA12/ATP 1 wt $\%$, g PA12/ATP 5 wt $\%$, h PA12/ATP 10 wt $\%$ with magnification of $10000 \times$ 


\section{Conclusions}

Polyamide 12 (PA12)/attapulgite (ATP) nanocomposites with different contents of ATP were successfully obtained using a simple mixing method based on the melt of the PA12 and consequent ATP dispersion in a high-speed thermokinetic homogenizer. ATP is potential filler for the production of PA12 matrix nanocomposites. The addition of ATP increased the modulus of elasticity, hardness, degree of crystallinity and apparent crystallite size of the compositions. The addition of up to $5 \mathrm{wt} \%$ of ATP increased tensile strength and deformation at break; after this addition, the concentration increased greatly and there was no good dispersion. ATP is a nanoclay found in Brazil and very little explored commercially. The use of ATP as a nanofiller to modify the mechanical properties of polyamides can be a potential advantage since there is no need to use compatibilizer agent and/or ATP surface functionalization to prepare the nanocomposites, increasing the range of PA12 applications.

Acknowledgements The authors are grateful to FAPESP (process 2014/04900-9, 2017/24873-4), CNPq (Conselho Nacional de Desenvolvimento Científico e Tecnológico, process 310196/2018-3) and CAPES for the financial support. This study was financed in part by the Coordenação de Aperfeiçoamento de Pessoal de Nível Superior - Brasil (CAPES) - Finance Code 001. The authors also thank Master Polymer (Brazil) for the donation of PA12.

\section{Compliance with ethical standards}

Conflict of interest The authors declare that they have no conflict of interest.

\section{References}

1. Barbalho GH (2018) Incorporação De Montmorilonita Organofílica Em Termoplásticos Para a Produção De Nanocompósitos. Holos 1:2-15. https://doi.org/10.15628/holos.2018.6008

2. Passador FR, Ruvolo-Filho AC, Pessan LA (2016) Structural, thermal, and gas transport properties of HDPE/LLDPE blend-based nanocomposites using a mixture of HDPE-g-MA and LLDPE-gMA as compatibilizer. Polym Eng Sci 56:765-775. https://doi. org/10.1002/pen.24305

3. Passador FR, Ruvolo F, Adhemar C, Pessan LA (2012) Caracterização estrutural de nanocompósitos de blendas HDPE/LLDPE e OMMT obtidos por diferentes sequências de mistura. Polímeros 22:357-363. https://doi.org/10.1590/S0104-142820120050000 52

4. Paz RA, Araújo EM, Pessan LA, Melo TJA, Leite AMD, Passador FR (2014) Influence of speed of processing in the mechanical and thermomechanical properties of polyamide 6 / organoclay nanocomposite. Materials Science Forum (Online) 775:383-387. https://doi.org/10.4028/www.scientific.net/MSF.775-776.383

5. Dağ SE, Bozkurt PA, Eroğlu F, Çelik M (2019) Preparation, characterization, and properties of polystyrene/Na-montmorillonite composites. J thermoplast compos 32:1078-1091. https://doi. org/10.1177/0892705718785691

6. Gautam A, Pragya K (2019) Synthesis of montmorillonite clay/ poly(vinyl alcohol) nanocomposites and their mechanical properties. J Nanosci Nanotechno 12:8071-8077. https://doi. org/10.1166/jnn.2019.16869

7. Oftadeh M, Hajati F, Jamshidi M, Naghash HJ (2019) Study of structure and thermal properties of styrene-butylacrylate copolymer with OMMT nanocomposite emulsions. Iran Chem Commun 7:63-70. https://doi.org/10.30473/ICC.2019.4234

8. Wei T, Jin K, Torkelson JM (2019) Isolating the effect of polymergrafted nanoparticle interactions with matrix polymer from dispersion on composite property enhancement: the example of polypropylene/halloysite nanocomposites. Polymer 176:38-50. https://doi.org/10.1016/j.polymer.2019.05.038

9. Wang Y, Liu C, Shi X, Liang J, Jia Z, Shi G (2019) Synergistic effect of halloysite nanotubes on flame resistance of intumescent flame retardant poly(butylene succinate) composites. Polym Compos 40:202-209. https://doi.org/10.1002/pc.24629

10. Mi X, Zhong L, Wei F, Zeng L, Zhang J, Zhang D, Xu T (2019) Fabrication of halloysite nanotubes/reduced graphene oxide hybrids for epoxy composites with improved thermal and mechanical properties. Polym Test 76:473-480. https://doi. org/10.1016/j.polymertesting.2019.04.007

11. Herrero M, Asensio M, Núñez K, Merino JC, Pastor JM (2019) Morphological, thermal, and mechanical behavior of polyamide11/sepiolite bio-nanocomposites prepared by melt compounding and in situ polymerization. Polym Compos 40:E704-E713. https://doi.org/10.1002/pc.24962

12. González-Ausejo J, Gámez-Pérez J, Balart R, Lagarón JM, Cabedo L (2019) Effect of the addition of sepiolite on the morphology and properties of melt compounded PHBV/ PLA blends. Polym Composite 40:E156-E168. https://doi. org/10.1002/pc.24538

13. García-Quiles L, Cuello AF, Castell P (2019) Sustainable materials with enhanced mechanical properties based on industrial polyhydroxyalkanoates reinforced with organomodified sepiolite and montmorillonite. Polymers 11(4):696. https://doi. org/10.3390/polym 11040696

14. Xavier KCM, Silva Filho EC, Santos MSF, Santos MRMC, Da Luz AB (2012) Caracterização Mineralógica, Morfológica e de Superfície da Atapulgita de Guadalupe-Pi. Holos 5:60. https://doi. org/10.15628/holos.2012.1111

15. da Luz AB, Lins FAF (2008) Rochas \& Minerais Industriais: Usos e Aplicações, 2nd edn. CETEM - Centro de Tecnologia Mineral, Rio de Janeiro

16. Xia Y, Zhu Y, Zhou Y, Nie W, Chen P (2018) Improved dispersion of attapulgite in polypropylene by grap oxide and the enhanced mechanical properties. Polym Compos 39:560-568. https://doi. org/10.1002/pc.23969

17. Bradley WF (1940) The structural scheme of attapulgite. Am Miner 25:405-410

18. Baltar CAM, da Luz AB, Baltar LM, de Oliveira CH, Bezerra FJ (2009) Influence of morphology and surface charge on the suitability of palygorskite as drilling fluid. Appl Clay Sci 42:597-600. https://doi.org/10.1016/j.clay.2008.04.008

19. Li X, Ni C, Yao C, Chen Z (2012) Development of attapulgite/ Ce 1-xZr xO 2 nanocomposite as catalyst for the degradation of methylene blue. Appl Catal B 117:118-124. https://doi. org/10.1016/j.apcatb.2012.01.008

20. Stathatos E, Papoulis D, Aggelopoulos CA, Panagiotaras D, Nikolopoulou A (2012) TiO 2/palygorskite composite nanocrystalline films prepared by surfactant templating route: synergistic effect to the photocatalytic degradation of an azo-dye in water. Hazard Mater 211:68-76. https://doi.org/10.1016/j.jhazm at.2011.11.055 
21. Wang K, Wang H, Pasupathi S, Linkov V, Ji S, Wang R (2012) Palygorskite promoted $\mathrm{PtSn} /$ carbon catalysts and their intrinsic catalytic activity for ethanol oxidation. Electrochim Acta 70:394-401. https://doi.org/10.1016/j.electacta.2012.03.111

22. Wang H, Wang X, Ma J, Xia P, Zhao J (2017) Removal of cadmium (II) from aqueous solution: a comparative study of raw attapulgite clay and a reusable waste-struvite/attapulgite obtained from nutrient-rich wastewater. J Hazard Mater 329:66-76. https://doi. org/10.1016/j.jhazmat.2017.01.025

23. Baltar MAC, Da Luz BA (2003) Insumos Minerais Para a Perfuração de Poços de Petróleo. Departamento de engenharia de minas - UFPE. Centro de tecnologia mineral - CETEM/MCT.https ://livroaberto.ibict.br/handle/1/938.

24. Canevarolo SV (2002) Ciência dos polímeros: Um texto básico para tecnólogos e engenheiros. $3^{\text {a }}$ reimpressão Revisada e ampliada. www.artliber.com.br.

25. Wiebeck H, Harada J (2005) Plásticos de Engenharia: Tecnologia e Aplicações. Editora Artliber, São Paulo

26. Peacock AJ (2016) Handbook of Polymers. Editora Chem Tec Publishing 1:246-250

27. Feng L, Wang $Y$, Wei Q (2019) PA12 powder recycled from SLS for FDM. Polymers (Basel) 11:727. https://doi.org/10.3390/polym 11040727

28. Shen L, Lin Y, Du Q, Zhong W, Yang Y (2005) Preparation and rheology of polyamide-6/attapulgite nanocomposites and studies on their percolated structure. Polymer 46:5758-5766. https://doi.org/10.1016/j.polymer.2005.05.040

29. Liu Y, Liu S, Yin C (2014) Synthesis and structure-property of polyamide 6/ macrogol/attapulgite nanocomposites. Polym Compos 1:1852-1857. https://doi.org/10.1002/pc.22840

30. Pan B, Yue Q, Ren J, Wang H, Jian L, Zhang J, Yang S (2006) A study on attapulgite reinforced PA6 composites. Polym Test 25:384-439. https://doi.org/10.1016/j.polymertes ting.2005.11.012

31. Pan B, Ren J, Yue Q, Liu B, Zhang J, Yang S (2009) Interfacial interactions and performance of polyamide $6 /$ modified attapulgite clay nanocomposites. Polym Compos 30:147-153. https://doi. org/10.1002/pc.20541

32. Xia L, Shentu B, Weng $Z$ (2015) A kinetic study of the thermal degradation of nylon-6/attapulgite nanocomposites. J Macromol Sci B 54:851-861. https://doi.org/10.1080/00222 348.2015.1042350

33. Benobeidallah B, Benhamida A, Dorigato A, Sola A, Messori M, Pegoretti A (2019) Structure and properties of polyamide 11 nanocomposites filled with fibrous palygorskite clay. Renew Mater 7:89-102. https://doi.org/10.32604/jrm.2019.00136

34. da Silva BC, dos Santos CM, de Couto O, Backes EH (2019) Evaluation of aging resistance in UHMWPE/LLDPE blend-based carbon nanotubes nanocomposites. Macromol Symp 383:1700079. https://doi.org/10.1002/masy.201700079

35. Silva TF, Menezes F, Montagna LS, Lemes AP, Passador FR (2018) Preparation and characterization of antistatic packaging for electronic components based on poly (lactic acid)/carbon black composites. J Appl Polym Sci 136:47273. https://doi. org/10.1002/app.47273

36. American Society for Testing and Materials (ASTM International) (2010) ASTM D256 - Standard test methods for determining the izod pendulum impact resistance of plastics 1-20. https://doi. org/10.1520/D0256-10.

37. American Society for Testing and Materials (ASTM International) (2015) ASTM D638-14 Standard Test Method for Tensile Properties of Plastics 1-17. https://doi.org/10.1520/D0638-14.1

38. Chen T, Wang $H$, Zhang $X$, Zheng $N$ (2008) SAED and HRTEM investigation of palygorskite. Acta Geol Sin 82:385-391. https ://doi.org/10.1111/j.1755-6724.2008.tb00588.x
39. Chisholm JE (1992) Powder-diffraction patterns and structural models for palygorskite. Can Miner 30:61-73

40. Christ CL, Hathaway JC, Hostetler PB, Anna O, Shepard US (1969) Palygorskite: new X-ray data. Am Mineral 54:198-205

41. Smirez M, Garcia-Romero E (2006) FTIR spectroscopic study of palygorskite: influence of the composition of the octahedral sheet. Appl Clay Sci 31:154-163. https://doi.org/10.1016/j. clay.2005.10.005

42. Khorami J, Lemieux A (1989) Comparison of attapulgites from different sources using TG/DTG and FTIR. Thermochim Acta 138:97-105. https://doi.org/10.1016/0040-6031(89)87244-2

43. Chen H, Zhao J, Zhong A, Jin Y (2011) Removal capacity and adsorption mechanism of heat-treated palygorskite clay for methylene blue. Chem Eng Trans 174:143-150. https://doi. org/10.1016/j.cej.2011.08.062

44. Cai Y, Xue J, Polya DA (2007) A Fourier transform infrared spectroscopic study of Mg-rich, Mg-poor and acid leached palygorskites. Spectrochim Acta A 66:282-288. https://doi. org/10.1016/j.saa.2006.02.053

45. Saiwari S, Sripornsawat B, Hayeemasae N (2019) Novel thermoplastic vulcanizates based on polyamide 12 blends: influence of modified devulcanized natural rubber gloves on properties of the blends. JMMM 29:25-31. https://doi.org/10.14456/ jmmm.2019.30

46. Kiziltas EE, Kiziltas A, Lee EC (2018) Structure and properties of compatibilized recycled polypropylene/recycled polyamide 12 blends with cellulose fibers addition. Polym Compos 39:35563563. https://doi.org/10.1002/pc.24376

47. Hassan $H$, Hocine NA, Médéric P, Deffarges MP, Poirot N (2015) Thermal and mechanical properties of PA12/C30B nanocomposites in relationship with nanostructure. J Appl Polym Sci 132(41938):41948. https://doi.org/10.1002/app.41938

48. Zhijiang C, Yi X, Haizheng Y, Jia J, Liu Y (2016) Poly(hydroxybutyrate)/cellulose acetate blend nanofiber scaffolds: Preparation, characterization and cytocompatibility. Mater Sci Eng C 58:757-767. https://doi.org/10.1016/j. msec.2015.09.048

49. El Miri N, El Achaby M, Fihri A, Larzek M, Zahouily M, Abdelouahdi K, Barakat A, Solhy A (2015) Synergistic effect of cellulose nanocrystals/graphene oxide nanosheets as functional hybrid nanofiller for enhancing properties of PVA nanocomposites. Carbohydr Polym 137:239-248. https://doi.org/10.1016/j.carbp ol.2015.10.072

50. Mi HY, Jing $X$, Peng J, Salick MR, Peng XF, Turng LS (2014) Poly(e-caprolactone) (PCL)/cellulose nano-crystal (CNC) nanocomposites and foams. Cellulose 21:2727-2741. https://doi. org/10.1007/s10570-014-0327-y

51. Chiu FC, Lai SM, Chen YL, Lee TH (2005) Investigation on the polyamide 6/organoclay nanocomposites with or without a maleated polyolefin elastomer as a toughener. Polymer 46:11600-11609. https://doi.org/10.1016/j.polymer.2005.09.077

52. De Oliveira MFL, De Oliveira MG, Leite MCAM (2011) Nanocompósitos de poliamida 6 e argila organofílica: Estudo da cristalinidade e propriedades mecânicas. Polimeros 21:78-82. https:// doi.org/10.1590/S0104-14282011005000015

53. Yuan M, Turng LS (2005) Microstructure and mechanical properties of microcellular injection molded polyamide- 6 nanocomposites. Polymer 46:7273-7292. https://doi.org/10.1016/j.polym er.2005.06.054

54. Yu S, Zhao J, Chen G, Juay YK, Yong MS (2007) The characteristics of polyamide layered-silicate nanocomposites. J Mater Process Technol 192:410-414. https://doi.org/10.1016/j.jmatprotec .2007 .04 .006

55. Varela T, Alberto GSC, de la Rosa JR, Gónzales V (2008) Nylon 6/ organoclay nanocomposites by extrusion teresa. J Appl Polym Sci 108:2923-2933. https://doi.org/10.1002/app 
56. Salmoria GV, Leite JL, Paggi RA (2009) The microstructural characterization of PA6/PA12 blend specimens fabricated by selective laser sintering. Polym Test 28:746-751. https://doi. org/10.1016/j.polymertesting.2009.06.010

57. Fernández CE, Bermúdez M, Alla A, Muñoz-Guerra S, Tocha E, Vancso GJ (2011) Compared structure and morphology of nylon-12 and 10-polyurethane lamellar crystals. Polymer 52:1515-1522. https://doi.org/10.1016/j.polymer.2011.02.008

58. Van Hooreweder B, Moens D, Boonen R, Kruth JP, Sas P (2013) On the difference in material structure and fatigue properties of nylon specimens produced by injection molding and selective laser sintering. Polym Test 32:972-981. https://doi.org/10.1016/j. polymertesting.2013.04.014

59. Atkins EDT, Hill MJ, Veluraja K (1995) Structural and morphological investigations of nylon 8 chain-folded lamellar crystals. Polymer 36:35-42. https://doi.org/10.1016/0032-3861(95)90672 $-\mathrm{O}$

60. Salmoria GV, Paggi RA, Lago A, Beal VE (2001) Microstructural and mechanical characterization of PA12/MWCNTs nanocomposite manufactured by selective laser sintering. Polym Test 30:611-615. https://doi.org/10.1016/j.polymertes ting.2011.04.007

61. Peng Z, Chen D (2006) Study on the nonisothermal crystallization behavior of poly(vinyl alcohol)/attapulgite nanocomposites by DSC analysis. J Polym Sci B 44:534-540. https://doi. org/10.1002/polb.20719
62. Thiré RM da SM, Arruda LC, Barreto LS (2011) Morphology and thermal properties of poly(3-hydroxybutyrate-co-3. hydroxyvalerate)/attapulgite nanocomposites. Mater Res Innov 14:340 344. https://doi.org/10.1590/S1516-14392011005000046

63. Ramos SMLS, de Carvalho LH, Spieth E, Rivadula RSM (1993) Efeitos da estabilização do Polipropileno nas propriedades térmicas, mecânicas e termo-mecânicas de compósitos de Polipropileno/ Atapulgita. Polímeros: Ciência e Tecnologia 3:26-31

64. Yuan M, Turng LS, Gong S, Winardi A (2004) Crystallization behavior of polyamide- 6 microcellular nanocomposites. J Cell Plast 40:397-409. https://doi.org/10.1177/0021955X04047220

65. Ozdilek CO, Kazimierczak K, Picken SJ (2005) Preparation and characterization of titanate-modified boehmite-polyamide-6 nanocomposites. Polymer 46:6025-6034. https://doi. org/10.1016/j.polymer.2005.05.065

66. Zago DM, Jikan SS, Badarulzaman NA, Nuhu AH, Bano N (2019) Investigation on structural, mechanical and melt flow properties of in situ polypropylene/kaolin nanocomposite. AIP Conf Proc 2068:1. https://doi.org/10.1063/1.5089403

67. Subramani C, Jamnik VS, Mhask ST (2008) Effect of attapulgite filler on the properties of nylon-6. Polym Compos 29:890-893. https://doi.org/10.1002/pc.20466

Publisher's Note Springer Nature remains neutral with regard to jurisdictional claims in published maps and institutional affiliations. 